OPEN ACCESS

Edited by:

Michael Gänzle,

University of Alberta, Canada

Reviewed by:

Yesim Ozogul,

Cukurova University, Turkey

Fatih Ozogul,

Çukurova University, Turkey

*Correspondence:

Ismail Fliss

ismail.fliss@fsaa.ulaval.ca

${ }^{\dagger}$ Present address:

Rajaa Benabbou,

LRI Laboratory, OSIL Team Research, ENSEM, University Hassan II,

Casablanca, Morocco

Specialty section:

This article was submitted to

Food Microbiology,

a section of the journal

Frontiers in Microbiology

Received: 09 April 2018 Accepted: 02 November 2018 Published: 26 November 2018

Citation:

Benabbou R, Subirade $M$ Desbiens M and Fliss I (2018) The Impact of Chitosan-Divergicin Film on Growth of Listeria monocytogenes in Cold-Smoked Salmon.

Front. Microbiol. 9:2824. doi: 10.3389/fmicb.2018.02824

\section{The Impact of Chitosan-Divergicin Film on Growth of Listeria monocytogenes in Cold-Smoked Salmon}

\author{
Rajaa Benabbou ${ }^{1 \dagger}$, Muriel Subirade ${ }^{1}$, Michel Desbiens ${ }^{2}$ and Ismail Fliss ${ }^{1 *}$ \\ ${ }^{1}$ Department of Food Science, Faculty of Agriculture and Food Sciences, Institute of Nutrition and Functional Foods, \\ Université Laval, Québec City, QC, Canada, ${ }^{2}$ Centre Technologique des Produits Aquatiques, Ministère de l'Agriculture des \\ Pêcheries et de l'Alimentation, Gaspé, QC, Canada
}

The aim of this study was to evaluate the impact of chitosan film, with bacteriocin divergicin 35 incorporate, on growth of Listeria monocytogenes in Cold smoked salmon. The simples of Cold-smoked wild salmon were inoculated with $L$. monocytogenes and treated with chitosan (100 kDa, 94.7\% de-acetylated) and divergicin M35 was stored for 3 weeks at $4-8^{\circ} \mathrm{C}$. The compounds were applied to the fish flesh in the form of solution or dried film. The film reduced $L$. monocytogenes to below the detection limit $(<50 \mathrm{cfu} / \mathrm{g})$ and kept total counts below $10^{4} \mathrm{cfu}$ per $\mathrm{g}$ compared to $10^{9} \mathrm{cfu}$ per $g$ in control samples while the effectiveness of the solution was very limited. The inhibitory activity of the film lasted for 3 weeks, while the solution had no effect on L. monocytogenes counts measured on day 14. The film provided a better preservation of fish color (redness) and firmness than others treatments, while the solution had little impact on these parameters. It kept the volatile basic nitrogen (17.5 mg N/100 g) below the control value $29.9 \mathrm{mg} \mathrm{N} / 100 \mathrm{~g}$. Divergicin-loaded chitosan film thus may represent an interesting alternative for the bio-preservation of cold-smoked fish.

Keywords: Listeria monocytogenes, divergicin M35, chitosan, chitosan-divergicin film, cold-smoked wild salmon

\section{INTRODUCTION}

Listeria monocytogenes is a foodborne human pathogen responsible for an estimated $28 \%$ of foodrelated deaths each year in the United States (Mead et al., 1999). On August 2008, Ready to eat products were responsible or a multi-state outbreak in Canada that resulted in 57 cases of listeriosis have been confirmed (mostely in Ontario), and 22 confirmed deaths (Public Health Agency of Canada, 2008). Compared to other foodborne pathogens, the mortality rate associated with L. monocytogenes infection is relatively high $(\sim 20 \%$ compared to $<1 \%$ for Salmonella or Escherichia coli O157) (Crerar et al., 1996; De Valk et al., 2005; Scallan et al., 2011). This pathogen is widespread in the environment and can grow in many food products (Alhogail et al., 2016).

Cold-smoked salmon is a good substrate for L. monocytogenes growth (Pelroy et al., 1994; Duffes, 1999; Katla et al., 2001; Brillet et al., 2005) because it offers favorable proliferation conditions such as, neutral $\mathrm{pH}$ and high water activity, which allow this organism to grow even at refrigeration temperatures. The prevalence of $L$. monocytogenes has been reported in several studies to be as 
high as $34-43 \%$ in cold-smoked salmon (Jorgensen and Huss, 1998). Ben Embarek (1994) reported values between 0 and $75 \%$ with an overall prevalence of $10 \%$, and Gombas et al. (2003) reported $4.31 \%$ in smoked seafood in Maryland and northern California in 2000 and 2001. The cold smoked salmon contamination with $L$. monocytogenes can be related to several factors such as cleaning and sanitation practices applied during cold smoked salmon production (Jorgensen and Huss, 1998; Johansson et al., 1999) the plant environment, the refrigerated storage and absence of guidance on the fundamental principles of microbiology, including testing for L. monocytogenes (Rotariu et al., 2014).

Bio-preservation has been proposed as means of improving food quality and safety. This approach is based on using protective bacterial cultures or antimicrobial compounds obtained there from, in particular bacteriocins, to control spoilage and pathogenic microorganisms such as L. monocytogenes (Nilsson et al., 1997; Tahiri et al., 2009). Different strategies have been described for the incorporation of bacteriocins into food matrices. These include direct inoculation with the producing strain, adding purified or semi-purified bacteriocin and immobilizing antimicrobial agents on solid supports such as polymer coatings or films (Fu et al., 2016). This latter approach offers several advantages over the other two, notably better protection of the active compound from inhibitors by decreasing its interaction with the food matrix, maintenance of a high concentration on the food surface, slow and continuous release during food storage and synergistic effects with antimicrobial properties of the polymer support (Coma et al., 2001, 2002; Cutter et al., 2001; Pranoto et al., 2005; Elsabee and Abdou, 2013).

Chitosan is a polymer obtained by deacetylation of chitin obtained from crustacean shells and fungi such as Aspergillus niger, Mucor rouxii, and Penicillium notatum (Tan et al., 1996; No et al., 2002; Qin et al., 2006). Chitosan is now widely recognized as non-toxic, biocompatible and biodegradable (Ye et al., 2008a). The Japanese department of health classified chitin and its derivatives as functional food ingredients in 1992. More recently (2001), the US FDA approved the GRAS status of chitosan. The capacity of chitosan to form films with excellent mechanical and physicochemical properties (Begin and Van Calsteren, 1999; Srinivasa et al., 2004; Suyatma et al., 2004) and to inhibit a wide variety of microorganisms (Shahidi et al., 1999; Agullo et al., 2003; Rinaudo, 2006; Moreira et al., 2011) makes it an interesting polymer for the development of films as antimicrobial delivery systems. Chitosan films containing added natural antimicrobial agents such as organic acids, essential oils, potassium sorbate, lysostaphin, polyphenols, sodium lactate, and bacteriocins have been shown to inhibit several pathogens in foods (Ouattara et al., 2000; Cha et al., 2003; Pranoto et al., 2005; He et al., 2016; Schelegueda et al., 2016; Nithya et al., 2018). Several studies have demonstrated the antimicrobial effect of chitosan films on pathogens in simple models with pure cultures (Pranoto et al., 2005; Li et al., 2006). A few more publications have used chitosanbase packaging films in food such as meat, poultry and fish (Beverlya et al., 2008; Higueras et al., 2013). The intrinsic activity of low-molecular-weight chitosan alone in combination with added antimicrobial compounds has rarely been investigated. To the best of our knowledge, no study has been published on the feasibility of using chitosan based film containing bacteriocin to improve the preservation of cold-smoked salmon during storage.

Divergicin M35 is a class IIa bacteriocin produced by a strain of Carnobacterium divergens M35 isolated by our group from frozen mussels (Tahiri et al., 2004). In a previous study, we showed synergetic inhibition by divergicin M35 and lowmolecular-weight chitosan against L. monocytogenes LSD532 (Benabbou et al., 2009). A bio-ingredient containing a mixture of $C$. divergens and divergicin M35 has been developed and found to be a strong inhibitor of Listeria on smoked salmon. Health Canada recently has approved this bio-ingredient as a new additive for smoked fish (Public Health Agency of Canada, 2016).

The aim of the present study was to evaluate the potential of chitosan-divergicin M35 film as an inhibitor of L. monocytogenes on cold-smoked salmon stored for 3 weeks at refrigerator temperatures and the impact of the antimicrobial film on the physical and chemical properties of this seafood product. The impact of chitosan-divergicin M35 film on growth of L. monocytogenes was compared with treatment using chitosandivergicin M35.

\section{MATERIALS AND METHODS}

\section{Materials}

Chitosan (100 kDa, 94.7\% de-acetylated) was obtained from DNP Canada inc. (Granby, QC, Canada). It was provided in $1 \%(\mathrm{v} / \mathrm{v})$ acetic acid and stored at $-20^{\circ} \mathrm{C}$ until use.

Divergicin M35 was produced and purified using a protocol similar to that previously described by (Tahiri et al., 2004) but adapted for higher culture supernatant volume. Purified divergicin M35 was obtained from supernatant of $C$. divergens M35 MRS culture. Supernatant $(500 \mathrm{ml})$ was heated in a water bath at $100^{\circ} \mathrm{C}$ for $10 \mathrm{~min}$ and then passed through an SPSepharose Fast Flow Cation Exchange Column (Amersham, Pharmacia Biotech, Uppsala, Sweden) at flow rate of $3 \mathrm{ml} / \mathrm{min}$. The column was then washed and equilibrated with 11 of ammonium acetate buffer $(5 \mathrm{mM}, \mathrm{pH} 5)$. The bacteriocin was eluted with $250 \mathrm{ml}$ of $1.5 \%$ (w/v) sodium chloride in ammonium acetate buffer, loaded onto a Sep-Pack C18 Cartridge micro-column (Waters, Milford, MA, United States) previously equilibrated with $5 \mathrm{mM}$ of $\mathrm{HCl}$ in HPLC grade water and eluted from the Sep-Pack with $60 \mathrm{ml}$ of $50 \%$ (v/v) acetonitrile in water. Acetonitrile was removed using a rotary evaporator. Bacteriocin was concentrated under vacuum with a Speed-Vac concentrator (Thermo Savant Instruments Inc., NY, United States) and kept at $-80^{\circ} \mathrm{C}$ until use. Antimicrobial activity of Divergicin M35 during the steps of purification against L. innocua HPB13 was confirmed using the agar diffusion method (Tagg et al., 1976).

Carnobacterium divergens M35 was grown in de Man, Rogosa and Sharpe (MRS) broth (De Man et al., 1960) obtained from Rosell Institute (Montreal, PQ, Canada) containing 0.1\% (v/v) Tween 80 and incubated aerobically at $30^{\circ} \mathrm{C}$. L. monocytogenes strain LSD532 (L. monocytogenes) was obtained from the Canadian Food Inspection Agency Laboratory Services Division 
(Ottawa, ON, Canada). L. innocua HPB13 (L. innocua, used as an indicator) was obtained from Health Protection Branch, Health and Welfare Canada (Ottawa, ON, Canada). Both strains were maintained as $20 \%$ glycerol stock at $-80^{\circ} \mathrm{C}$. L. innocua and L. monocytogenes were grown aerobically at $30^{\circ} \mathrm{C}$ and $37^{\circ} \mathrm{C}$, respectively, in tryptic soy broth (TSB, Difco Laboratories, Sparks, MD, United States) supplemented with $0.6 \%(\mathrm{w} / \mathrm{v})$ yeast extract (YE, Difco).

\section{Film-Forming Solution and Film Preparation}

Chitosan-divergicin M35 (C-M35) solution was prepared by blending stock solutions to obtain $0.125 \mathrm{mg} / \mathrm{ml}$ divergicin M35 and $6.25 \mathrm{mg} / \mathrm{ml}$ chitosan in $1 \%(\mathrm{v} / \mathrm{v})$ acetic acid.

Chitosan-divergicin M35 film was prepared by pouring $145 \mathrm{ml}$ of solution into Petri dishes to a height of $1 \mathrm{~cm}$ and drying the liquid in a laminar flow hood for $72 \mathrm{~h}$ at ambient temperature. The resulting film was peeled and used directly for each experiment. Chitosan film was made also without divergicin M35 for comparison.

\section{Preparation of $L$. monocytogenes Inoculum}

Listeria monocytogenes was grown in TSBYE at $37^{\circ} \mathrm{C}$ and cells were harvested by centrifugation at 7,500 $\times g$ for $15 \mathrm{~min}$ at $4^{\circ} \mathrm{C}$, washed twice with sterilized phosphate buffer saline: PBS (0.01 M phosphate, $\mathrm{pH} 7.2$ ) and re-suspended in $10 \mathrm{ml}$ of PBS. Buffer was added to obtain a final concentration of approximately $10^{5} \mathrm{cfu} / \mathrm{ml}$. Dilutions were plated on TSBYE plates and incubated aerobically at $37^{\circ} \mathrm{C}$ for $24 \mathrm{~h}$ before determining viable cell counts.

\section{Assays With Cold-Smoked Salmon}

Cold-smoked wild Pacific sockeye salmon (hereinafter 'fish') was provided by Fumoir Grizzly Inc. (St-Augustin, Québec, Canada) and used immediately upon reception. The flesh was cut into squares $(3 \mathrm{~cm}, 4 \mathrm{~g})$ and divided into six groups corresponding to the following treatments:

Treatment A: control (untreated) samples.

Treatment B: $100 \mu \mathrm{l}$ of L. monocytogenes suspension $\left(10^{5} \mathrm{cfu} / \mathrm{ml}\right)$ spread on one side of each square $\left(2.5 \times 10^{3} \mathrm{cfu} / \mathrm{g}\right)$.

Treatment C: $100 \mu \mathrm{l}$ of C-M35 solution spread on the side inoculated with L. monocytogenes.

Treatment D: inoculated squares covered with $9 \mathrm{~cm}^{2}$ of C-M35 film.

Treatment E: un-inoculated squares coated with $100 \mu \mathrm{l}$ of C-M35 solution.

Treatment F: un-inoculated squares covered with $9 \mathrm{~cm}^{2}$ of C-M35 film.

The experiments were performed in duplicate and each simple was analyzed twice. Simples were dried for $10 \mathrm{~min}$ in a laminarflow biological safety cabinet, wrapped in oxygen permeable film obtained from Fumoir Grizzly Inc., and incubated for 21 days under the conditions suggested by AFNOR (Association Française de Normalisation NF V 45-065, 1997): 14 days at $4^{\circ} \mathrm{C}$ followed by 7 days at $8^{\circ} \mathrm{C}$. These conditions are designed to simulate changes in temperature during storage and handling in commercial and domestic environments.

Color, texture and total volatile basic nitrogen (TVBN) were determined at $1,7,14$, and 21 days of storage. Microbial composition, $\mathrm{pH}$ and antimicrobial activity were determined at $1,3,7,14$, and 21 days of storage.

\section{Microbiological Analysis}

The whole $4 \mathrm{~g}$ sample was placed in a sterile filtering stomacher bag (Seward Medical, London, United Kingdom) with peptone water $(0.1 \% \mathrm{w} / \mathrm{v})$ to obtain a $1 / 10$ dilution (i.e., $36 \mathrm{ml})$. For treatment D, the C-M35 film was removed first and the films were processed the same way (in $36 \mathrm{ml}$ of peptone water) for measurement of the residual inhibition activity. Bag contents were homogenized for 3 min using a Stomacher 400 circulator (Seward, Therfford, Norfolk, United Kingdom). The filtered homogenate was serially diluted 10 -fold in peptone water and dilutions were spread-plated in duplicate on appropriate selective media. For L. monocytogenes, CM0856 Listeria selective medium supplemented with SR140 Listeria selective supplement (Oxoid Ltd., Basingstoke, Hampshire, England) was used and plates were incubated aerobically at $37^{\circ} \mathrm{C}$ for $48-72 \mathrm{~h}$. Total lactic acid bacteria (LAB) were enumerated on nitrite actidion polymyxin (NAP) agar (Davidson and Cronin, 1973). NAP medium consists of APT agar (Difco Laboratories) supplemented with Polymyxin B (0.003 g/l), cycloheximide $(0.01 \mathrm{~g} / \mathrm{l})$ and $\mathrm{NaNO}_{2}(0.6 \mathrm{~g} / \mathrm{l})$, all obtained from Sigma-Aldrich (Oakville, Ontario, Canada). Plates were incubated aerobically at $25^{\circ} \mathrm{C}$ for $48 \mathrm{~h}$. For the determination of the total viable bacterial counts, dilutions were spread-plated on plate count agar (PCA, Difco Laboratories, Sparks, MD, United States) and incubated aerobically at $30^{\circ} \mathrm{C}$ for $48 \mathrm{~h}$.

\section{Antimicrobial Activity}

Residual inhibitory activity in fish and film in treatments $C$ and $\mathrm{D}$ was determined by centrifuging homogenate $(7,500 \times g$ for $15 \mathrm{~min})$ at $4^{\circ} \mathrm{C}$ and filtering the supernatant using sterile syringe filters $(0.45 \mu \mathrm{m}$, Corning, Germany). The agar diffusion method and a quantitative critical dilution micro-method (Tahiri et al., 2004) were used with L. innocua HPB13.

\section{Physical and Chemical Analysis}

Color parameters L, 'a' and 'b' (brightness, redness and yellowness) were measured using a Minolta Chroma Meter CR300 (Minolta Camera Co., Ltd., Osaka, Japan) with the CIE color system (CIE, 1996). Measurements were made after standardizing the instrument with light source D and the measuring head was rotated $90^{\circ}$ between duplicate measurements at each position. Two fish samples per treatment (A, E, and F only) were measured four times each and the mean of the 8 measurements was used for statistical analyses.

Total volatile basic nitrogen (TVBN) production was determined by a distillation procedure (Pearson, 1976) and the $\mathrm{pH}$ of the homogenate was measured.

Texture profile analysis (TPA) involved using a Texture Analyzer TA.XT2 (Stable Micro Systems, Texture Technologies 
Corps, Scarsdale, NY, United States) with double compression. Firmness was defined as the peak force of the first compression and cohesiveness was defined as the ratio of the total energy required for the second compression to that of the first compression. The probe (a flat-ended cylinder $4 \mathrm{~mm}$ in diameter) descended at a constant speed of $1 \mathrm{~mm} / \mathrm{s}$. Four measurements were performed on each of two samples per treatment and the mean value was used for statistical analyses.

\section{Statistical Analyses}

Statistical analyses were performed based on duplicate and each simple was analyzed twice. Statistical analyses were performed using STATGRAPHICS plus 4.1 (Manugistics Inc., Rockville, MD, United States). Significant differences among the treatment means of each parameter were tested by analysis of variance. Treatment comparisons were performed using Fisher's leastsignificant differences (LSD) test with a $P$-value of $\leq 0.05$ considered significant.

\section{RESULTS}

\section{Microbiological Analysis}

The antimicrobial activity of divergicin M35 during the steps of purification was confirmed using the agar diffusion test (Figure 1). A clear zone of inhibition of L. innocua HPB 13 was obtained around the well, confirming anti-listerial activity.

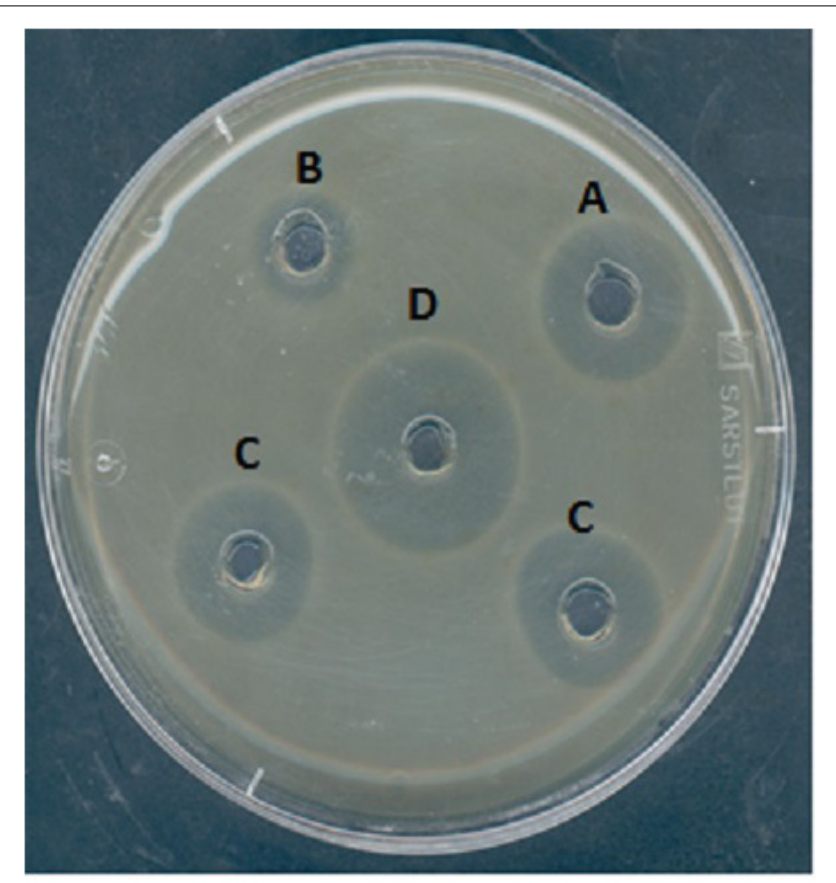

FIGURE 1 | Inhibition of Listeria innocua HPB13 by divergicin M35 from Carnobacterium divergens M35 culture supernatant (A), eluate from SP-Sepharose column (B), eluate from Sep-Pack C18 column (C) and purified divergicin M35 (D).
Figure 2 represents the antimicrobial activity of C-M35 solution and film against L. monocytogenes in fish flesh stored at refrigerator temperatures. By day 3, the viable count was about 1 log lower in fish coated with inhibitor solution than in the control, and this difference increased only slightly throughout the storage. There was no reduction in viable count after 14 days of storage. However, the film reduced the count to below the detection limit ( $<50 \mathrm{cfu} / \mathrm{g}$ ) from the 1st day of storage.

Total aerobic counts on these samples are shown in Figure 3. The chitosan-divergicin M35 solution had no effect on the total aerobic count. In contrast, the film had a strong effect, differing from the control by $1.8 \mathrm{log}$ and $5.8 \mathrm{log}$ cycles, respectively, on days 3 and 21 .

The effects of C-M35 solution and film on total lactic acid bacteria are illustrated in Figure 4. For all treatments except film, the total lactic acid bacteria counts increased progressively during the 21 days of storage, while counts were below the detection limit $(<50 \mathrm{cfu} / \mathrm{g})$ throughout storage with the film.

Counts of L. monocytogenes, total aerobes and lactic acid bacteria in the film homogenate were below the detection limit $(<50 \mathrm{cfu} / \mathrm{g})$, indicating that no detectable viable cells remained attached to the film (data not shown).

\section{Residual Antimicrobial Activity in Fish and Chitosan Films}

Residual inhibitory activity in the fish treated with C-M35 solution and film and in the C-M35 film after storage is shown in Table 1. For the entire 21-day period, no activity was obtained from fish treated with solution. However, residual activity was detected in fish treated with the film, decreasing significantly over days 1-14 and ending up at $2.3 \times 10^{3}$ on day 21 . A residual activity was observed in the film removed after 1 day of storage, decreasing progressively over 14 days and then stabilizing at $4.61 \times 10^{3}$ through to day 21 . Fish treated with chitosan solution or film without bacteriocin contained no inhibitory activity, confirming that the residual activity detected was due to divergicin M35 (results not shown).

\section{Physical and Chemical Analysis of Fish Samples}

The effect of C-M35 solution and film on the color values of un-inoculated fish is shown in Table 2. Differences in lightness (L) between the control and the treatment with solution were significant after 14 days of storage, although no significant difference was observed after 21 days. Application of the film did not produce any significant difference in the $L$-value during the 1st week, although a significant increase was observed thereafter. The redness (a) values of control and solution-treated fish were the same after 1 week but were significantly different after 14 days of storage. For fish treated with film, the redness values were higher than those of the control. The C-M35 solution and film, respectively, resulted in decreased and increased yellowness (b) compared to the control until 21 days of storage. Figure 5 shows the overall appearance and difference in color between the treatments after 21 days of storage. The difference in redness matches the measured (a) values. 


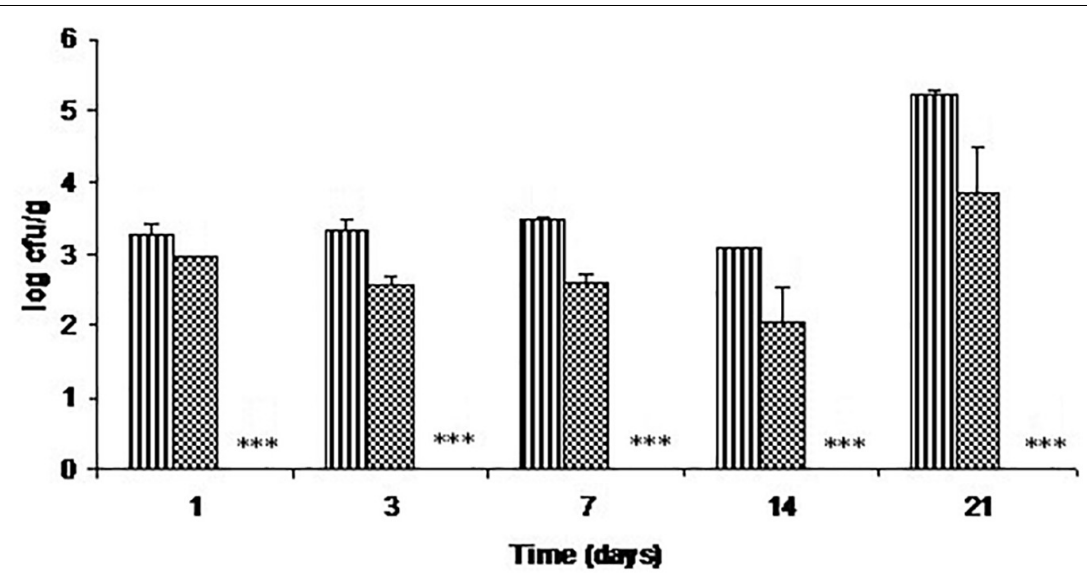

FIGURE 2 | Growth of L. monocytogenes on cold-smoked wild salmon during storage at $4^{\circ} \mathrm{C}$ for 14 days then at $8^{\circ} \mathrm{C}$ for 7 days: stripe pattern represents untreated fish, checker pattern represents treatment with C-M35 solution; values for the C-M35 film treatment (***) were below the detection limit (<50 cfu/g).

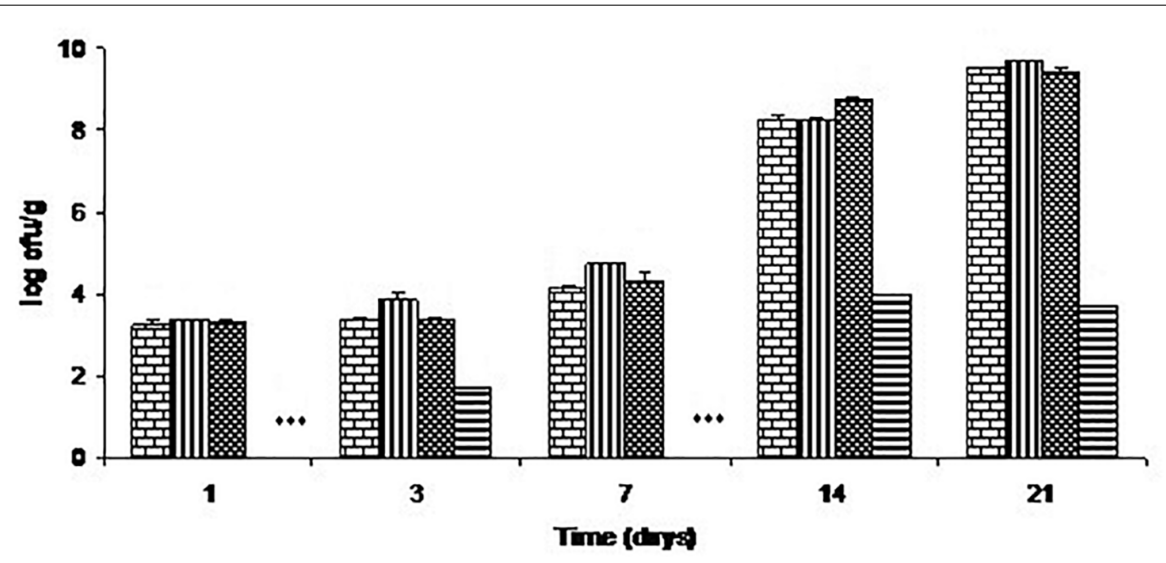

FIGURE 3 | Growth of total aerobes on cold-smoked wild salmon during storage at $4^{\circ} \mathrm{C}$ for 14 days then at $8^{\circ} \mathrm{C}$ for 7 days: brick pattern represents the control, striped represents fish inoculated with L. monocytogenes, tight weave represents the C-M35 solution treatment and horizontal stripe represents the C-M35 film treatment. ${ }^{* * *}$ Values were below the detection limit $(<50 \mathrm{cfu} / \mathrm{g})$.

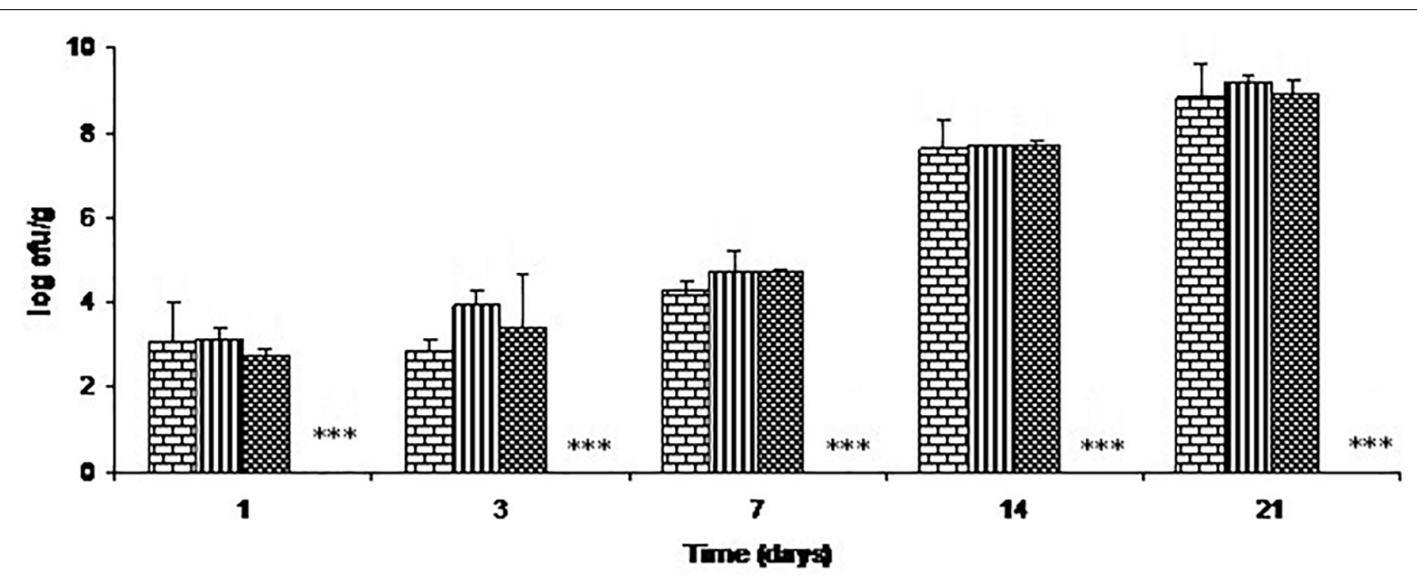

FIGURE 4 | Growth of lactic acid bacteria on cold-smoked wild salmon during storage at $4^{\circ} \mathrm{C}$ for 14 days then at $8^{\circ} \mathrm{C}$ for 7 days: brick pattern represents the control, stripe represents fish inoculated with L. monocytogenes, tight weave represents treatment with C-M35 solution; values for fish covered with C-M35 film (***) were below the detection limit (<50 cfu/g). 
TABLE 1 | Residual divergicin activity (arbitrary units) in homogenate of cold-smoked wild salmon and its chitosan-divergicin $\mathrm{M} 35$ film covering after 14 days at $4^{\circ} \mathrm{C}$ followed by 7 days at $8^{\circ} \mathrm{C}$, determined by the agar diffusion test (a) and the critical dilution micro-method (b).

\begin{tabular}{|c|c|c|c|c|c|c|c|c|c|c|}
\hline \multirow{2}{*}{$\begin{array}{l}\text { Day } \\
\text { Method }\end{array}$} & \multicolumn{2}{|c|}{1} & \multicolumn{2}{|c|}{3} & \multicolumn{2}{|c|}{7} & \multicolumn{2}{|c|}{14} & \multicolumn{2}{|c|}{21} \\
\hline & $\mathbf{a}$ & b & a & b & a & b & $\mathbf{a}$ & b & a & b \\
\hline 1 & & $4.61 \times 10^{3 a}$ & & $2.30 \times 10^{3 c}$ & & $2.30 \times 10^{3 c}$ & & $5.76 \times 10^{2 b}$ & & $2.30 \times 10^{3 c}$ \\
\hline 2 & & $3.69 \times 10^{4 a}$ & & $1.84 \times 10^{4 b}$ & & $9.22 \times 10^{3 c}$ & & $4.61 \times 10^{3 d}$ & & $4.61 \times 10^{3 d}$ \\
\hline 3 & & 0 & & 0 & & 0 & & 0 & & 0 \\
\hline
\end{tabular}

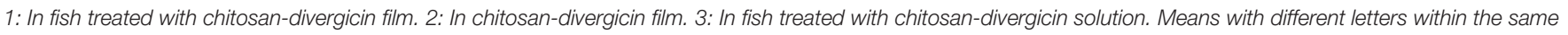
row are significantly different $(P<0.05)$.

TABLE 2 | Color parameters $L$, $a$, and $b$ for cold smoked wild salmon during storage at $4^{\circ} \mathrm{C}$ for 14 days then $8^{\circ} \mathrm{C}$ for 7 days, $\mathrm{A}$ : control, E: fish coated with chitosan-divergicin solution, F: fish covered with chitosan-divergicin film.

\begin{tabular}{|c|c|c|c|c|}
\hline \multirow{2}{*}{$\begin{array}{l}\text { Color } \\
\text { parameter }\end{array}$} & \multirow[t]{2}{*}{ Day } & \multicolumn{3}{|c|}{ Treatment } \\
\hline & & $A$ & $E$ & $\boldsymbol{F}$ \\
\hline \multirow[t]{4}{*}{$\mathbf{L}$} & 1 & $48.01 \pm 1.12^{\mathrm{hg}}$ & $47.01 \pm 1.07^{h}$ & $48.81 \pm 2.37^{f g}$ \\
\hline & 7 & $49.89 \pm 0.91^{\text {def }}$ & $50.42 \pm 0.87^{\text {cde }}$ & $49.17 \pm 2.69^{e f g}$ \\
\hline & 14 & $48.80 \pm 1.12^{\mathrm{fg}}$ & $52.74 \pm 0.97^{a}$ & $51.31 \pm 0.63^{b c}$ \\
\hline & 21 & $49.86 \pm 1.84^{\text {def }}$ & $50.67 \pm 1.15^{\mathrm{bcd}}$ & $52.05 \pm 0.48^{a b}$ \\
\hline \multirow[t]{4}{*}{ a } & 1 & $32.99 \pm 2.03^{b c d}$ & $32.46 \pm 1.31^{\mathrm{cd}}$ & $34.63 \pm 1.58^{a}$ \\
\hline & 7 & $33.07 \pm 1.73^{\mathrm{bcd}}$ & $31.65 \pm 1.03^{d}$ & $35.15 \pm 0.60^{a}$ \\
\hline & 14 & $34.86 \pm 1.82^{a}$ & $29.00 \pm 1.40^{\mathrm{e}}$ & $34.15 \pm 0.65^{a b}$ \\
\hline & 21 & $32.95 \pm 2.22^{\mathrm{bcd}}$ & $28.15 \pm 2.13^{\mathrm{e}}$ & $33.86 \pm 0.71^{a b c}$ \\
\hline \multirow[t]{4}{*}{ b } & 1 & $32.38 \pm 1.55^{\mathrm{drf}}$ & $29.71 \pm 1.33^{\mathrm{g}}$ & $34.39 \pm 2.27^{a b c}$ \\
\hline & 7 & $34.02 \pm 1.12^{\mathrm{bc}}$ & $31.76 \pm 1.31^{f}$ & $34.73 \pm 2.11^{a b c}$ \\
\hline & 14 & $33.75 \pm 1.63^{\mathrm{cd}}$ & $31.89 \pm 1.06^{\mathrm{ef}}$ & $35.90 \pm 1.03^{a}$ \\
\hline & 21 & $33.43 \pm 2.70^{c d e}$ & $28.83 \pm 0.96^{9}$ & $35.47 \pm 0.82^{a b}$ \\
\hline
\end{tabular}

Means \pm std with different letters for the same color parameter are significantly different $(P<0.05)$.

Figure 6 shows the firmness (A) and cohesiveness (B) profiles of the stored fish samples. Firmness increased in samples treated with solution, although no significant difference was observed compared to the control. For fish treated with film, there was a significant difference throughout the storage period in the firmness value compared to the control. The solution did not affect cohesiveness significantly during the storage. The cohesiveness value of fish treated with film was the same after 1 week of storage compared to the control and decreased significantly after 14 days of storage.

The $\mathrm{pH}$ of fish treated with C-M35 solution was stable, ranging between 5.9 and 6 during the 21 days of storage, and no significant difference was observed compared to the control (data not shown). Application of the film resulted in a decrease to 5.5 after 1 day of storage and this value was maintained throughout the 3 weeks of storage. TVBN production increased from 10.3 to $30.4 \mathrm{mg} \mathrm{N} / 100 \mathrm{~g}$ in solution-treated samples over the 21 days, which was similar to the control range of 12.4-29.9 mg N/100 g (results not shown). Application of the film slowed TVBN production significantly to $17.5 \mathrm{mg} \mathrm{N} / 100 \mathrm{~g}$ at the end of the 21 days.

\section{DISCUSSION}

The efficacy of bacteriocins as bio-preservatives is influenced by various food matrix parameters and by the form in which they are applied. One of the most promising strategies proposed to enhance efficacy is incorporation into polymer films. Polymerbased films allow direct contact with the food surface and therefore continuous release of the antimicrobial compound, allowing the maintenance of inhibitory activity on food surfaces (Quintavalla and Vicini, 2002; Ture et al., 2011; Fu et al., 2016).

The combination of a natural polymer such as chitosan (by itself somewhat inhibitory) with a natural soluble inhibitor such as divergicin M35 is a plausible strategy for suppressing bacterial growth in ready-to-eat products and one that may be acceptable to consumers. Our work has shown clearly that this combination does inhibit L. monocytogenes on coldsmoked salmon and much more when applied as a film, in which case it can keep viable counts below the detection limit ( $<50 \mathrm{cfu} / \mathrm{g}$ ) for 21 days. Since L. monocytogenes did not infiltrate the film, we can conclude that inhibition was complete. This was no doubt due to a continuous release of divergicin M35. Previous studies have shown that antimicrobial effects of active films in various food systems depend on the nature and concentration of the antimicrobial agent used. Ye et al. (2008b) increased the anti-L. monocytogenes activity of chitosancoated plastic film on cold-smoked salmon by incorporating 

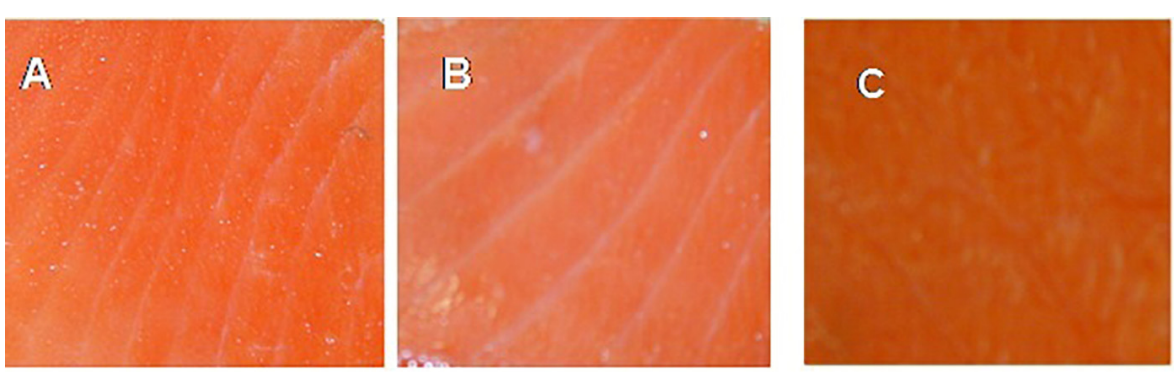

FIGURE 5 | Appearance of cold-smoked wild salmon flesh at the end of 21 days of storage (14 days at $4^{\circ} \mathrm{C}$ then 7 days at $8^{\circ} \mathrm{C}$ ): control (A), coated with C-M35 solution (B), covered with C-M35 film (C).

\section{A}

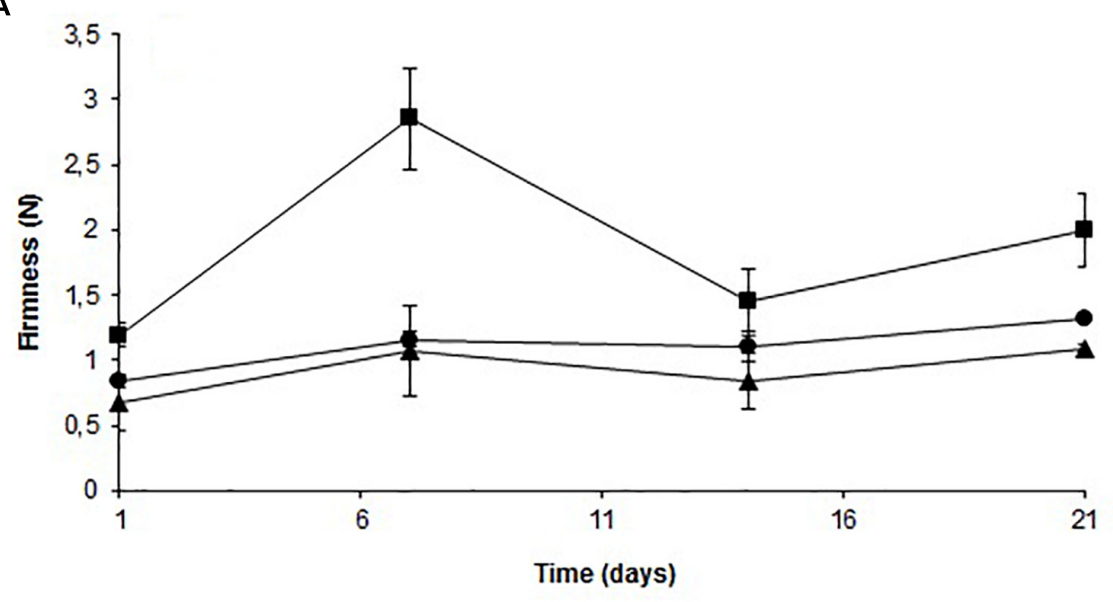

B

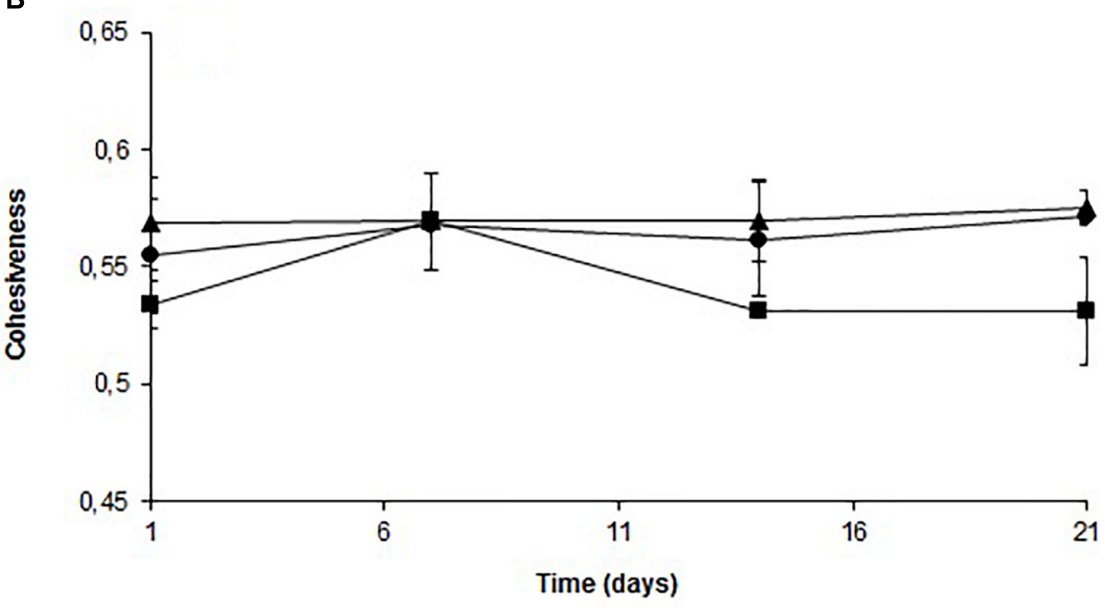

FIGURE 6 | Evolution of firmness (A) and cohesiveness (B) of cold-smoked wild salmon during storage at $4^{\circ} \mathrm{C}$ for 14 days followed by $8^{\circ} \mathrm{C}$ for 7 days: triangle represents control, octagon represents treatment with C-M35 solution and square represents treatment with C-M35 film.

sodium lactate alone or with nisin or potassium sorbate. They obtained similar results on ham steaks by incorporating with these compounds as well as sodium diacetate or sodium benzoate Ye et al. (2008a). Sodium lactate was the most effective in this case. Marcos et al. (2007) found that alginate was superior to zein and polyvinyl alcohol as an enhancer of L. monocytogens inhibition by enterocin at 200 or 2,000 units per $\mathrm{cm}^{2}$.

The weak anti-listerial activity and absence of residual activity of the C-M35 solution in the sample homogenate is likely due to 
interactions between the bacteriocin and food components such as lipids as well as partial inactivation by endogenous proteases produced in situ by other microorganisms (Katla et al., 2001; VazVelho et al., 2005). Aasen et al. (2003) showed that more than $80 \%$ of the sakacin $\mathrm{P}$ added to cold-smoked salmon and chicken was adsorbed to proteins. The antimicrobial activity of inhibitory substances in cold-smoked salmon may also be affected by added salt. Devlieghere et al. (2004) observed that adding $\mathrm{NaCl}$ to a medium decreased the antimicrobial activity of chitosan, due to interaction between $\mathrm{Cl}^{-}$ions and positive charges on the chitosan and to competition of $\mathrm{Na}^{+}$for the negative charges on the microbial cell surface, and that antimicrobial activity also depended on $\mathrm{pH}$ and the isoelectric point of proteins in the food matrix. These phenomena probably affect bacteriocin activity, whether free or in film. However, continuous release of divergicin M35 during storage may minimize such losses. Our results showed that the fish and the film covering contained residual activity of divergicin M35 during the 21 days of storage. The difference in activity added and activity recovered in the film and fish is probably due to the phenomena mentioned above.

The total aerobic and lactic acid bacteria counts as well as TVBN production suggest that the antimicrobial solution was practically ineffective while the antibacterial film was quite effective. Since initial levels of bacteria in this salmon product were low, the bacteriocin-loaded chitosan film reduced these to below the limit of detection. Ye et al. (2008a) also obtained a substantial reduction in total and anaerobic counts using their chitosan-coated plastic film loaded with antimicrobial agents. The microbiological results obtained in our study demonstrate the potential of divergicin-loaded chitosan film for extending the shelf life of cold-smoked salmon. Previous reports that chitosan inhibits the growth of a wide variety of microorganisms (Shahidi et al., 1999; Jeon et al., 2002; Agullo et al., 2003; Rinaudo, 2006; Yingyuad et al., 2006). However, and to the best of our knowledge, no study has been published on application of chitosan based film containing bacteriocin to improve the preservation of coldsmoked salmon during storage.

In the present study, we were also interested in the impact of chitosan-divergicin M35 film on the physical and chemical characteristics of the fish product. The increase in firmness during the 1st week of storage was likely due to moisture loss, while changes during the 2 nd week could be due to proteases produced by spoilage microorganisms (Morzel et al., 1997) or to autolytic enzymes in the fish flesh (Stoknes and Rustad, 1995). The significant differences obtained with film were probably related to the strong affinity of chitosan $\mathrm{NH}_{2}$ groups for water molecules ( $\mathrm{Wu}$ et al., 2004). The increase in the firmness of film-covered fish during the last week of storage may be due to the onset of film breakdown. The cohesiveness of these samples decreased slightly during the last week of storage, which was consistent with the changes in the muscle strength retention capacity after the first compression.

Increased brightness (L) and decreased redness and yellowness ( $\mathrm{a}$ and b) values of C-M35 solution-treated compared to untreated fish are consistent with previous observations. Jo et al. (2001) observed similar changes in brightness and redness for sausage containing chitosan as a preservative. Tahiri et al. (2009) reported a significant decrease of the yellowness value of divergicin-M35-treated cold-smoked salmon stored for 21 days at $4^{\circ} \mathrm{C}$. The increased in redness of film-covered samples is probably due to decreased breakdown of carotenoids because of the low oxygen permeability of chitosan film (Xu et al., 2005). The loss of water from the sample may also result in increased pigment concentration (Choubert et al., 1992).

For all treatments, the TVBN concentration was below the acceptable maximum proposed by various authors (Civera et al., 1995; Leroi et al., 2001). The C-M35film-covered samples thus showed a higher hygienic quality compared to the control and solution-treated samples. TVBN concentration is considered a major quality index for cold-smoked salmon (Leroi et al., 2001; Brillet et al., 2005). These low concentrations could be a result of reduced counts of spoilage bacteria due the effect of the C-M35 film. Jeon et al. (2002) reported reductions in TVBN of $33-50 \%$ and $26-51 \%$ in chitosan-glycerol-coated cod and herring, respectively, at the end of 12 days of storage at $4^{\circ} \mathrm{C}$.

\section{CONCLUSION}

In this study, the combination of chitosan and divergicin M35 was more effective for inhibiting L. monocytogenes in coldsmoked wild salmon when applied as a film rather than as a solution. The film reduced $L$. monocytogenes to below detection limit $(<50 \mathrm{cfu} / \mathrm{g})$. The film was shown to maintain acceptable color and texture of this fish product during 3 weeks of storage at refrigerator temperatures. This represents an extension of product shelf life. Additional studies using sensory evaluation panels should be conducted before considering commercial application of such films.

\section{AUTHOR CONTRIBUTIONS}

RB was the Ph.D. student in charge of performing all the laboratory work. $\mathrm{RB}$ also was in charge of the preparation of the manuscript. MS was in charge of the laboratory work related to the preparation and characterization of divergicinchitosan films. MD was involved in the preparation and study of the antimicrobial activity of divergicin M35 and chitosan. IF supervised the entire work and was in charge of the microbiological aspects of the work.

\section{FUNDING}

Financial support for this research was received from the Conseil des Recherches en Pêche et en Agroalimentaire du Québec (CORPAQ) and the Ministère de l'Agriculture, des Pêcheries et de l'Alimentation du Québec (MAPAQ).

\section{ACKNOWLEDGMENTS}

We thank Stephen Davids for critical reading of the manuscript. 


\section{REFERENCES}

Aasen, I. M., Markussen, S., Moretro, T., Katla, T., Axelsson, L., and Naterstad, K. (2003). Interactions of the bacteriocins sakacin $\mathrm{P}$ and nisin with food constituents. Int. J. Food. Microbiol. 87, 35-43. doi: 10.1016/S0168-1605(03) 00047-3

Agullo, E., Rodriguez, M. S., Ramos, V., and Albertengo, L. (2003). Present and future role of chitin and chitosan in food. Macromol. Biosci. 3, 521-530. doi: 10.1002/mabi.200300010

Alhogail, S., Suaifan, G. A. R. Y., and Zourob, M. (2016). Rapid colorimetric sensing platform for the detection of Listeria monocytogenes foodborne pathogen. Biosens. Bioelectron. 86, 1061-1066. doi: 10.1016/j.bios.2016.07.043

Begin, A., and Van Calsteren, M. R. (1999). Antimicrobial films produced from chitosan. Int. J. Biol. Macromol. 26, 63-67. doi: 10.1016/S0141-8130(99)00064-1

Ben Embarek, P. K. (1994). Presence, detection and growth of Listeria monocytogenes in seafoods - A review. Int. J. Food Microbiol. 23, 17-34. doi: 10.1016/0168-1605(94)90219-4

Benabbou, R., Zihler, A., Desbiens, M., Kheadr, E., Subirade, M., and Fliss, I. (2009). Inhibition of Listeria monocytogenes by a combination of chitosan and divergicin M35. Can. J. Microbiol. 55, 347-355. doi: 10.1139/W08-154

Beverlya, R. L., Janes, M. E., Prinyawlwatkula, W., and No, H. K. (2008). Edible chitosan films on ready-to-eat roast beef for the control of Listeria monocytogenes. Food Microbiol. 25, 534-537. doi: 10.1016/j.fm.2007.11.002

Brillet, A., Pilet, M. F., Prevost, H., Cardinal, M., and Leroi, F. (2005). Effect of inoculation of Carnobacterium divergens V41, a biopreservative strain against Listeria monocytogenes risk, on the microbiological, chemical and sensory quality of cold-smoked salmon. Int. J. Food Microbiol. 104, 309-324. doi: 10. 1016/j.ijfoodmicro.2005.03.012

Cha, D. S., Cooksey, K., Chinnan, M. S., and Park, H. J. (2003). Release of nisin from various heat-pressed and cast films. LWT Food Sci. Technol. 36, 209-213. doi: 10.1016/S0023-6438(02)00209-8

Choubert, G., Blanc, J. M., and Courvalin, C. (1992). Muscle carotenoid content and color of farmed rainbow-trout fed astaxanthin or canthaxanthin as affected by cooking and smoke-curing procedures. Int. J. Food Sci. Technol. 27, 277-284. doi: 10.1111/j.1365-2621.1992.tb02029.x

Civera, T., Parisi, E., Amerio, G. P., and Giaccone, V. (1995). Shelf-life of vacuum-packed smoked salmon - Microbiological and chemical-changes during storage. Arch. Lebensmittelhyg. 46, 13-17.

Coma, V., Martial-Gros, A., Garreau, S., Copinet, A., Salin, F., and Deschamps, A. (2002). Edible antimicrobial films based on chitosan matrix. J. Food Sci. 67, 1162-1169. doi: 10.1111/j.1365-2621.2002.tb09470.x

Coma, V., Sebti, I., Pardon, P., Deschamps, A., and Pichavant, F. H. (2001). Antimicrobial edible packaging based on cellulosic ethers, fatty acids, and nisin incorporation to inhibit Listeria innocua and Staphylococcus aureus. J. Food Prot. 64, 470-475. doi: 10.4315/0362-028X-64.4.470

Crerar, S., Dalton, C., Longbottom, H., and Kraa, E. (1996). Foodborne disease: current trends and future surveillance needs in Australia. Med. J. Aus. 165, 672-675.

Cutter, C. N., Willett, J. L., and Siragusa, G. R. (2001). Improved antimicrobial activity of nisin-incorporated polymer films by formulation change and addition of food grade chelator. Lett. Appl. Microbiol. 33, 325-328. doi: 10.1046/ j.1472-765X.2001.01005.X

Davidson, C., and Cronin, F. (1973). Medium for the selective enumeration of lactic acid bacteria from foods. Appl. Microbiol. 26, 439-440.

De Man, J. C., Rogosa, M., and Sharpe, E. (1960). A medium for the cultivation of Lactobacilli. J. Appl. Bacteriol. 23, 130-135. doi: 10.1111/j.1365-2672.1960. tb00188.x

De Valk, H., Jacquet, C., Goulet, V., Vaillant, V., Perra, A., Simon, F., et al. (2005). Surveillance of Listeria infections in Europe. Euro. Surveill. 10, 251-255. doi: 10.2807/esm.10.10.00572-en

Devlieghere, F., Vermeulen, A., and Debevere, J. (2004). Chitosan: antimicrobial activity, interactions with food components and applicability as a coating on fruit and vegetables. Food Microbiol. 21, 703-714. doi: 10.1016/j.fm.2004. 02.008

Duffes, F. (1999). Improving the control of Listeria monocytogenes in cold smoked salmon. Trends Food Sci. Technol. 10, 211-216. doi: 10.1016/S0924-2244(99) 00051-5
Elsabee, M, Z., and Abdou, E. S. (2013). Chitosan based edible films and coatings: a review. Mater. Sci. Eng. C Mater. Biol. Appl. 33, 1819-1841. doi: 10.1016/j.msec. 2013.01.010

Fu, Y., Sarkar, P., Bhunia, A. K., and Yao, Y. (2016). Delivery systems of antimicrobial compounds to food. Trends Food Sci. Technol. 57, 165-177. doi: 10.1016/j.tifs.2016.09.013

Gombas, D. E., Chen, Y., Clavero, R. S., and Scott, V. N. (2003). Survey of Listeria monocytogenes in ready-to-eat foods. J. Food Prot. 66, 559-569. doi: 10.4315/ 0362-028X-66.4.559

He, L., Zou, L., Yang, Q., Xia, J., Zhou, K., Zhu, Y., et al. (2016). Antimicrobial activities of nisin, tea polyphenols, and chitosan and their combinations in chilled mutton. J. Food Sci. 81, 1466-1471. doi: 10.1111/1750-3841.13312

Higueras, L., Lopez-Carballo, G., Hernandez-Munoz, P., Gavara, R., and Rollini, M. (2013). Development of a novel antimicrobial film based on chitosan with LAE (ethyl-N 2784785 -dodecanoyl-L-arginate) and its application to fresh chicken. Int. J. Food Microbiol. 165, 339-345. doi: 10.1016/j.ijfoodmicro.2013.06.003

Jeon, Y. J., Kamil, J., and Shahidi, F. (2002). Chitosan as an edible invisible film for quality preservation of herring and Atlantic cod. J. Agric. Food Chem. 50, 5167-5178. doi: 10.1021/jf0116931

Jo, C., Lee, J. W., Lee, K. H., and Byun, M. W. (2001). Quality properties of pork sausage prepared with water-soluble chitosan oligomer. Meat Sci. 59, 369-375. doi: 10.1016/S0309-1740(01)00089-4

Johansson, T., Rantala, L., Palmu, L., and Honkanen-Buzalski, T. (1999). Occurrence and typing of Listeria monocytogenes strains in retail vacuumpacked fish products and in a production plant. Int. J. Food Microbiol. 47, 111-119. doi: 10.1016/S0168-1605(99)00019-7

Jorgensen, L. V., and Huss, H. H. (1998). Prevalence and growth of Listeria monocytogenes in naturally contaminated seafood. Int. J. Food Microbiol. 42, 127-131. doi: 10.1016/S0168-1605(98)00071-3

Katla, T., Moretro, T., Aasen, I. M., Holck, A., Axelsson, L., and Naterstad, K. (2001). Inhibition of Listeria monocytogenes in cold smoked salmon by addition of sakacin P and/or live Lactobacillus sakei cultures. Food Microbiol. 18, 431439. doi: 10.1006/fmic. 2001.0420

Leroi, F., Joffraud, J. J., Chevalier, F., and Cardinal, M. (2001). Research of quality indices for cold-smoked salmon using a stepwise multiple regression of microbiological counts and physico-chemical parameters. J. Appl. Microbiol. 90, 578-587. doi: 10.1046/j.1365-2672.2001.01283.x

Li, B., Kennedy, J. F., Peng, J. L., Yie, X., and Xie, B. J. (2006). Preparation and performance evaluation of glucomannan-chitosan-nisin ternary antimicrobial blend film. Carbohydr. Polym. 65, 488-494. doi: 10.1016/j.carbpol.2006.02.006

Marcos, B., Aymerich, T., Monfort, J. M., and Garriga, M. (2007). Use of antimicrobial biodegradable packaging to control Listeria monocytogenes during storage of cooked ham. Int. J. Food Microbiol. 120, 152-158. doi: 10. 1016/j.ijfoodmicro.2007.06.003

Mead, P. S., Slutsker, L., Dietz, V., McCaig, L. F., Bresee, J. S., Shapiro, C., et al. (1999). Food-related illness and death in the United States. Emerg. Infect. Dis. 5, 607-625. doi: 10.3201/eid0505.990502

Moreira, M. D., Pereda, M., Marcovich, N. E., and Roura, S. I. (2011). Antimicrobial effectiveness of bioactive packaging materials from edible chitosan and Casein polymers: assessment on carrot, cheese, and salami. J. Food Sci. 76, 54-63. doi: 10.1111/j.1750-3841.2010.01910.x

Morzel, M., Fitzgerald, G. F., and Arendt, E. K. (1997). Fermentation of salmon fillets with a variety of lactic acid bacteria. Food Res. Int. 30, 777-785. doi: 10.1016/S0963-9969(98)00045-3

Nilsson, L., Huss, H. H., and Gram, L. (1997). Inhibition of Listeria monocytogenes on cold-smoked salmon by nisin and carbon dioxide atmosphere. Int. J. Food Microbiol. 38, 217-227. doi: 10.1016/S0168-1605(97)00111-6

Nithya, S., Nimal, T. R., Baranwal, G., Suresh, M. K., CPA, Anil Kumar, V., et al. (2018). Preparation, characterization and efficacy of lysostaphin-chitosan gel against Staphylococcus aureus. Int. J. Biol. Macromol. 110, 157-166. doi: 10. 1016/j.ijbiomac.2018.01.083

No, H. K., Park, N. Y., Lee, S. H., and Meyers, S. P. (2002). Antibacterial activity of chitosans and chitosan oligomers with different molecular weights. Int. J. Food Microbiol. 74, 65-72. doi: 10.1016/S0168-1605(01)00717-6

Ouattara, B., Simard, R. E., Piette, G., Begin, A., and Holley, R. A. (2000). Diffusion of acetic and propionic acids from chitosan-based antimicrobial packaging films. J. Food Sci. 65, 768-773. doi: 10.1111/j.1365-2621.2000.tb13584.x 
Pearson. (1976). The Chemical Analysis of Foods, 7th Edn. Londres: Churchill Livingstone, 383-393.

Pelroy, G., Peterson, M., Paranjpye, R., Almond, J., and Eklund, M. (1994). Inhibition of Listeria monocytogenes in cold-process (smoked) salmon by sodium-nitrite and packaging method. J. Food Prot. 57, 114-119. doi: 10.4315/ 0362-028X-57.2.114

Pranoto, Y., Rakshit, S. K., and Salokhe, V. M. (2005). Enhancing antimicrobial activity of chitosan films by incorporating garlic oil, potassium sorbate and nisin. Lwt-Food Sci. Technol. 38, 859-865. doi: 10.1016/j.lwt.2004.09.014

Public Health Agency of Canada (2008). Listeria monocytogenes outbreak. Available at: http://www.phac-aspc.gc.ca/alert-alerte/listeria/listeria_2008-eng.php

Public Health Agency of Canada (2016). Notice of Health Canada's Proposal to Enable the Use of a New Food Additive, Carnobacterium Divergens M35, as an Antimicrobial Preservative in Sliced Ready-to-Eat Cold-Smoked Salmon and Sliced Ready-to-Eat Cold-Smoked Trout - NOP/AVP-0018. https://www. canada.ca/en/health-canada/services/food-nutrition/public-involvementpartnerships/proposal-use-new-food-additive-carnobacterium-divergensantimicrobial-preservative-sliced-ready-cold-smoked-salmon-sliced.html

Qin, C. Q., Li, H. R., Xiao, Q., Liu, Y., Zhu, J. C., and Du, Y. M. (2006). Watersolubility of chitosan and its antimicrobial activity. Carbohydr. Polym. 63, 367-374. doi: 10.1016/j.carbpol.2005.09.023

Quintavalla, S., and Vicini, L. (2002). Antimicrobial food packaging in meat industry. Meat Sci. 62, 373-380. doi: 10.1016/S0309-1740(02)00121-3

Rinaudo, M. (2006). Chitin and chitosan: properties and applications. Prog. Polym. Sci. 31, 603-632. doi: 10.1016/j.progpolymsci.2006.06.001

Rotariu, O., Thomas, D. J. I., Goodburn, K., Hutchison, M. L., and Strachan, N. J. C. (2014). Smoked salmon industry practices and their association with Listeria monocytogenes. Food Control 35, 284-292. doi: 10.1016/j.foodcont.2013.07.015

Scallan, E., Hoekstra, R., Angulo, F., Tauxe, R., Widdowson, M., Roy, S., et al. (2011). Foodborne illness acquired in the United States-major pathogens. Emerg. Infect. Dis. 17, 7-15. doi: 10.3201/eid1701.P11101

Schelegueda, L. I., Zalazar, A. L., Gliemmo, M. F., and Campos, C. A. (2016). Inhibitory effect and cell damage on bacterial flora of fish caused by chitosan, nisin and sodium lactate. Int. J. Biol. Macromol. 83, 396-402. doi: 10.1016/j. ijbiomac.2015.11.033

Shahidi, F., Arachchi, J. K. V., and Jeon, Y. J. (1999). Food applications of chitin and chitosans. Trends Food Sci. Technol. 10, 37-51. doi: 10.1016/S0924-2244(99) 00017-5

Srinivasa, P. C., Ramesh, M. N., Kumar, K. R., and Tharanathan, R. N. (2004). Properties of chitosan films prepared under different drying conditions. J. Food Eng. 63, 79-85. doi: 10.1016/S0260-8774(03)00285-1

Stoknes, I., and Rustad, T. (1995). Proteolytic activity in muscle from atlantic salmon (salmo-salar). J. Food Sci. 60, 711-714. doi: 10.1111/j.1365-2621.1995. tb06212.x

Suyatma, N. E., Copinet, A., Tighzert, L., and Coma, V. (2004). Mechanical and barrier properties of biodegradable films made from chitosan and poly (lactic acid) blends. J. Polym. Environ. 12, 1-6. doi: 10.1023/B:JOOE.0000003121. $12800.4 \mathrm{e}$

Tagg, J. R., Adnan, A. S., and Wanna-Maker, L. W. (1976). Bacteriocins of gram-positive bacteria. Bacteriol. Rev. 40, 722-756.
Tahiri, I., Desbiens, M., Benech, R., Kheadr, E., Lacroix, C., Thibault, S., et al. (2004). Purification, characterization and amino acid sequencing of divergicin M35: a novel class IIa bacteriocin produced by Carnobacterium divergens M35. Int. J. Food Microbiol. 97, 123-136. doi: 10.1016/j.ijfoodmicro.2004. 04.013

Tahiri, I., Desbiens, M., Kheadr, E., Lacroix, C., and Fliss, I. (2009). Comparison of different application strategies of divergicin M35 for inactivation of Listeria monocytogenes in cold-smoked wild salmon. Food Microbiol. 26, 783-793. doi: $10.1016 /$ j.fm.2009.05.003

Tan, S. C., Tan, T. K., Wong, S. M., and Khor, E. (1996). The chitosan yield of zygomycetes at their optimum harvesting time. Carbohydr. Polym. 30, 239-242. doi: 10.1016/S0144-8617(96)00052-5

Ture, H., Eroglu, E., Ozen, B., and Soyer, F. (2011). Effect of biopolymers containing natamycin against Aspergillus niger and Penicillium roquefortii on fresh kashar cheese. Int. J. Food Sci. Technol. 46, 154-160. doi: 10.1111/j.13652621.2010.02465.x

Vaz-Velho, M., Todorov, S., Ribeiro, J., and Gibbs, P. (2005). Growth control of Listeria innocua 2030c during processing and storage of cold-smoked salmontrout by Carnobacterium divergens V41 culture and supernatant. Food Control 16, 541-549. doi: 10.1016/j.foodcont.2004.05.012

Wu, Y. B., Yu, S. H., Mi, F. L., Wu, C. W., Shyu, S. S., Peng, C. K., et al. (2004). Preparation and characterization on mechanical and antibacterial properties of chitsoan/cellulose blends. Carbohydr. Polym. 57, 435-440. doi: 10.1016/j. carbpol.2004.05.013

Xu, Y. X., Kim, K. M., Hanna, M. A., and Nag, D. (2005). Chitosan-starch composite film: preparation and characterization. Ind. Crops Prod. 21, 185-192. doi: 10.1016/j.indcrop.2004.03.002

Ye, M., Neetoo, H., and Chen, H. (2008a). Control of Listeria monocytogenes on ham steaks by antimicrobials incorporated into chitosan-coated plastic films. Food Microbiol. 25, 260-268. doi: 10.1016/j.fm.2007.10.014

Ye, M., Neetoo, H., and Chen, H. (2008b). Effectiveness of chitosan-coated plastic films incorporating antimicrobials in inhibition of Listeria monocytogenes on cold-smoked salmon. Int. J. Food Microbiol. 127, 235-240. doi: 10.1016/j. ijfoodmicro.2008.07.012

Yingyuad, S., Ruamsin, S., Reekprkhon, D., Douglas, S., Pongamphai, S., and Siripatrawan, U. (2006). Effect of chitosan coating and vacuum packaging on the quality of refrigerated grilled pork. Packag. Technol. Sci. 19, 149-157. doi: $10.1002 /$ pts. 717

Conflict of Interest Statement: The authors declare that the research was conducted in the absence of any commercial or financial relationships that could be construed as a potential conflict of interest.

Copyright (c) 2018 Benabbou, Subirade, Desbiens and Fliss. This is an open-access article distributed under the terms of the Creative Commons Attribution License (CC BY). The use, distribution or reproduction in other forums is permitted, provided the original author(s) and the copyright owner(s) are credited and that the original publication in this journal is cited, in accordance with accepted academic practice. No use, distribution or reproduction is permitted which does not comply with these terms. 